Polymer Journal, Vol. 38, No. 12, pp. 1230-1236 (2006)

(C)2006 The Society of Polymer Science, Japan

\title{
Novel Synthesis of Surface-Block Dendrimer Using [4+4] Photocycloaddition of Anthryl Dendrons
}

\author{
Yasushi Yanagimoto, Yutaka TAKAguchi, ${ }^{\dagger}$ and Sadao Tuboi \\ Graduate School of Environmental Science, Okayama University, Tsushima-Naka 3-1-1, Okayama 700-8530, Japan
}

(Received July 25, 2006; Accepted September 11, 2006; Published October 26, 2006)

\begin{abstract}
Novel surface-block dendrimer was synthesized via a divergent/convergent approach using [4+4] photocycloaddition of two different anthracenes bearing a newly designed dendritic substituent, of which terminal groups are long alkyl chains for one hemisphere and oligo(ethylene oxide) chains for the other hemisphere. A solution of the two different anthryl dendrons was irradiated with a high-pressure mercury lamp to afford a hetero-dimer, which consists of the two different dendrons. The surface-block dendrimer was isolated by the use of size exclusion chromatography (SEC) and well characterized by NMR spectrum, SEC, and MALDI-TOF-Mass spectrum. Furthermore, this paper describes a ratio of the photoproducts (the hetero-dimer and two homo-dimers) that were obtained from the photocycloaddition reactions carried out in neat and an emulsion condition, along with the solution.

[doi:10.1295/polymj.PJ2006082]

KEY WORDS Surface-Block Dendrimer / Photodimerization / Anthracene / Emulsion / Divergent/Convergent Approach /
\end{abstract}

Dendritic macromolecules (dendrimers) have received considerable attention during the past three decades. ${ }^{1-5}$ Since the physicochemical properties of dendrimers depend remarkably on their structural characteristics, there is an increasing emphasis on syntheses of surface-block dendrimers, which have a spherical shape where the surface character of one hemisphere is different from that of the other, in order to provide future development of dendrimer-based smart materials. ${ }^{6-15}$ Recently, Percec and co-workers reported a new concept to provide bilayered supramolecular architectures; the Janus-dendritic system. ${ }^{16}$ Several methods of preparation of surface-block dendrimers have already been developed: a convergent approach, ${ }^{7-9}$ a divergent/convergent approach, ${ }^{10,11}$ and a divergent/divergent approach. ${ }^{12-15}$ Although the divergent/convergent approach is quite useful for combinatorial synthesis of surface-block dendrimers, only a few examples have been reported so far. Furthermore, the formation of surface-block dendrimer by the use of photoreaction of the focal point of two different hemispherical dendrons has never been described. Recently, we have reported the synthesis and photodimerization of a poly(amidoamine) dendron having an anthracene moiety at the focal point. ${ }^{17-23}$ During our studies on photoreactivities of anthracene bearing the dendritic substituent, we found that $[4+4]$ photocycloaddition of anthracene moieties of two different dendrons gave the surface-block dendrimer. This paper describes the facile synthesis of surface-block dendrimer by the use of photocycloaddition of two different anthryl dendrons, of which terminal groups are long alkyl chains for one hemisphere and oligo(ethylene oxide) chains for the other hemisphere.

\section{EXPRIMENTAL}

NMR spectra were measured on a Bruker AVANCE400 spectrometer. Matrix-assisted laser desorption ionization time-of-flight mass spectroscopy (MALDI-TOF-Mass) was performed on a Voyager Elite mass spectrometer using dithranol (1,8-dihdroxy-9[10H]-anthracenone) as a matrix. Size-exclusion chromatography (SEC) experiments were performed on a Japan Analytical Industry Co. model LC-918V with GS-320 columns (eluent: methanol) or JAIGEL 1H, 2.5H (eluent: chloroform). Photoirradiation was carried out in a Pyrex reactor. A $500 \mathrm{~W}$ high-pressure mercury lamp was used as the light source.

Reagents were obtained from Wako Pure Chemical Industries Ltd., Tokyo Kasei Co. Ltd., Kanto Kagaku Co., Ltd., or Aldrich Chemical Co. Inc. Dimethylformamide (DMF), acetonitrile, and ethanol used in reactions were further purified by general methods. Other solvents and reagents were used as received without further purification. Dendrons 1 and $\mathbf{2}$ were synthesized according to a previously reported method. ${ }^{17}$

\section{Preparation of Hydrophobic Dendron 3}

A mixture of thionyl chloride $(2.09 \mathrm{~g}, 17.6 \mathrm{mmol})$ and octadecanoic acid $(500 \mathrm{mg}, 1.76 \mathrm{mmol})$ was stirred for $3 \mathrm{~h}$ at $80^{\circ} \mathrm{C}$. The excess reagent was removed

${ }^{\dagger}$ To whom correspondence should be addressed (Tel/Fax: +81-86-251-8903, E-mail: yutaka@cc.okayama-u.ac.jp). 
under reduced pressure and the residue was dried at $60^{\circ} \mathrm{C}$ under vacuum to give octadecanoyl chloride as thick oil $(550 \mathrm{mg})$, which was used for the next step without further purification. The octadecanoyl chloride was added to a solution of $\mathbf{1}(364 \mathrm{mg}, 0.320$ $\mathrm{mmol})$, DMF $(3.0 \mathrm{~mL})$, and triethylamine $(176 \mathrm{mg}$, $1.74 \mathrm{mmol}$ ) at $0{ }^{\circ} \mathrm{C}$, and the solution was stirred for $24 \mathrm{~h}$ at $45^{\circ} \mathrm{C}$ under a nitrogen atmosphere. Water $(3.0 \mathrm{~mL})$ was added and the solution was stirred for $10 \mathrm{~min}$. After removal of the solvent under reduced pressure at $45{ }^{\circ} \mathrm{C}$, the residue was triturated with boiling THF $(10 \mathrm{~mL})$ and aqueous $\mathrm{Na}_{2} \mathrm{CO}_{3}(2.0 \mathrm{~g} / 20 \mathrm{~mL})$. After drying under reduced pressure, the crude product was purified by silica gel column chromatography (eluent, chloroform $/$ methanol $=10 / 1$ ) to afford dendron 3 (92 mg, $0.0443 \mathrm{mmol}$ ) in $12 \%$ yield: ${ }^{1} \mathrm{H}$ NMR $\left(400 \mathrm{MHz}, \mathrm{CDCl}_{3} / \mathrm{CD}_{3} \mathrm{OD}=10 / 1\right) \delta 0.94(\mathrm{t}, J=7.6$ $\mathrm{Hz}, 12 \mathrm{H}), 1.21-1.29(\mathrm{~m}, 120 \mathrm{H}), 2.16(\mathrm{t}, J=7.6 \mathrm{~Hz}$, $8 \mathrm{H}), 2.31-2.35(\mathrm{~m}, 12 \mathrm{H}), 2.52-2.55(\mathrm{~m}, 6 \mathrm{H}), 2.69-$ $2.81(\mathrm{~m}, 12 \mathrm{H}), 3.22-3.30(\mathrm{~m}, 22 \mathrm{H}), 5.48(\mathrm{~s}, 2 \mathrm{H}), 7.51$ $(\mathrm{t}, J=8.0 \mathrm{~Hz}, 2 \mathrm{H}), 7.57(\mathrm{t}, J=8.0 \mathrm{~Hz}, 2 \mathrm{H}), 8.07(\mathrm{~d}$, $J=8.0 \mathrm{~Hz}, 2 \mathrm{H}), 8.29(\mathrm{~d}, J=8.0 \mathrm{~Hz}, 2 \mathrm{H}), 8.52(\mathrm{~s}$, $1 \mathrm{H}$ ); MALDI-TOF-Mass for $\mathrm{C}_{121} \mathrm{H}_{215} \mathrm{~N}_{15} \mathrm{O}_{12}: \mathrm{m} / z$ calcd., $2073.11\left[\mathrm{MH}^{+}\right], 2095.09\left[\mathrm{MNa}^{+}\right]$; found: 2073.50, 2095.79.

\section{Preparation of Hydrophobic Dendron 4}

A mixture of thionyl chloride $(1.19 \mathrm{~g}, 10.0 \mathrm{mmol})$ and octadecanoic acid $(284 \mathrm{mg}, 1.00 \mathrm{mmol})$ was stirred for $3 \mathrm{~h}$ at $80^{\circ} \mathrm{C}$. The excess reagent was removed under reduced pressure, and the residue was dried at $60{ }^{\circ} \mathrm{C}$ under vacuum to give octadecanoyl chloride as thick oil (303 mg), which was used for the next step without further purification. The octadecanoyl chloride was added to a solution of 2 (150 mg, 0.0780 $\mathrm{mmol})$, DMF $(2.0 \mathrm{~mL})$, and triethylamine $(100 \mathrm{mg}$, $0.990 \mathrm{mmol})$ at $0{ }^{\circ} \mathrm{C}$, and the solution was stirred for $24 \mathrm{~h}$ at $45^{\circ} \mathrm{C}$ under a nitrogen atmosphere. Water $(2.0 \mathrm{~mL})$ was added, and the solution was stirred for 10 min. After removal of the solvent under reduced pressure at $45^{\circ} \mathrm{C}$, the residue was triturated with boiling THF $(5 \mathrm{~mL})$ and aqueous $\mathrm{Na}_{2} \mathrm{CO}_{3}(500 \mathrm{mg} /$ $12.5 \mathrm{~mL}$ ). After drying under reduced pressure, the crude product was purified by silica gel column chromatography (eluent, chloroform/methanol $=4 / 1$ ) to afford the dendron $4(10 \mathrm{mg}, 0.00246 \mathrm{mmol})$ in $4 \%$ yield: ${ }^{1} \mathrm{H}$ NMR $\left(400 \mathrm{MHz}, \mathrm{CDCl}_{3} / \mathrm{CD}_{3} \mathrm{OD}=10 / 1\right)$ $\delta 0.89(\mathrm{t}, J=7.6 \mathrm{~Hz}, 12 \mathrm{H}), 1.22-1.28(\mathrm{~m}, 240 \mathrm{H})$, $2.18(\mathrm{t}, J=7.6 \mathrm{~Hz}, 16 \mathrm{H}), 2.20-2.30(\mathrm{~m}, 28 \mathrm{H}), 2.52-$ $2.57(\mathrm{~m}, 14 \mathrm{H}), 2.71-2.90(\mathrm{~m}, 28 \mathrm{H}), 3.25-3.35(\mathrm{~m}$, $46 \mathrm{H}), 5.47(\mathrm{~s}, 2 \mathrm{H}), 7.51(\mathrm{t}, J=8.0 \mathrm{~Hz}, 2 \mathrm{H}), 7.57$ $(\mathrm{t}, J=8.0 \mathrm{~Hz}, 2 \mathrm{H}), 8.07(\mathrm{~d}, J=8.0 \mathrm{~Hz}, 2 \mathrm{H}), 8.29$ (d, $J=8.0 \mathrm{~Hz}, 2 \mathrm{H}$ ), 8.52 (s, 1H): MALDI-TOF-Mass for $\mathrm{C}_{234} \mathrm{H}_{433} \mathrm{~N}_{31} \mathrm{O}_{24}: \mathrm{m} / z$ calcd., $4051.11\left[\mathrm{MH}^{+}\right]$, $4074.092\left[\mathrm{MNa}^{+}\right]$; found: 4052.18, 4074.10.

\section{Preparation of Hydrophobic Dendron 5}

To a solution of dendron $1(200 \mathrm{mg}, 0.199 \mathrm{mmol})$ in $\mathrm{EtOH} / \mathrm{CH}_{3} \mathrm{CN}(1 / 1: 3 \mathrm{~mL})$ was added DIPEA $(N, N-$ diisopropylethylamine) (172 $\mathrm{mg}, 1.33 \mathrm{mmol})$, nonanoic acid $(151 \mathrm{mg}, 0.955 \mathrm{mmol})$, and HOBt (1-hydroxybenzotriazole) $(180 \mathrm{mg}, 1.33 \mathrm{mmol})$. After stirring for $5 \mathrm{~min}$ at room temperature under a nitrogen atmosphere, EDC (1-ethyl-3-(dimethylaminopropyl)carbodiimide) hydrochloride $(255 \mathrm{mg}, 1.33 \mathrm{mmol}$ ) was added. After stirring at room temperature for $24 \mathrm{~h}$, the mixture was evaporated. The residue was dissolved in chloroform/methanol (10/1: $20 \mathrm{~mL})$, washed with aqueous saturated $\mathrm{NaCl}(10 \mathrm{~mL})$, and concentrated. The crude product was purified by silica gel column chromatography using eluent (chloroform/methanol $=10 / 1)$ to afford dendron $5(182 \mathrm{mg}, 0.116$ mmol) in $58 \%$ yield: ${ }^{1} \mathrm{H} \mathrm{NMR}\left(400 \mathrm{MHz}, \mathrm{CDCl}_{3} /\right.$ $\left.\mathrm{CD}_{3} \mathrm{OD}=10 / 1\right) \delta 0.94(\mathrm{t}, J=7.6 \mathrm{~Hz}, 12 \mathrm{H}), 1.21-$ $1.29(\mathrm{~m}, 48 \mathrm{H}), 2.16(\mathrm{t}, J=7.6 \mathrm{~Hz}, 8 \mathrm{H}), 2.31-2.35(\mathrm{~m}$, $12 \mathrm{H}), 2.52-2.55(\mathrm{~m}, 6 \mathrm{H}), 2.69-2.81(\mathrm{~m}, 12 \mathrm{H}), 3.22-$ $3.30(\mathrm{~m}, 22 \mathrm{H}), 5.48(\mathrm{~s}, 2 \mathrm{H}), 7.51(\mathrm{t}, J=8.0 \mathrm{~Hz}, 2 \mathrm{H})$, $7.57(\mathrm{t}, J=8.0 \mathrm{~Hz}, 2 \mathrm{H}), 8.07(\mathrm{~d}, J=8.0 \mathrm{~Hz}, 2 \mathrm{H})$, $8.29(\mathrm{~d}, J=8.0 \mathrm{~Hz}, 2 \mathrm{H}), 8.52(\mathrm{~s}, 1 \mathrm{H})$; MALDI-TOFMass for $\mathrm{C}_{121} \mathrm{H}_{215} \mathrm{~N}_{15} \mathrm{O}_{12}: \mathrm{m} / z$ calcd., $1568.15\left[\mathrm{MH}^{+}\right]$; found: 1567.65 .

\section{Preparation of Hydrophilic Dendron 6}

A mixture of thionyl chloride $(407 \mathrm{mg}, 3.43 \mathrm{mmol})$ and [2-(2-methoxyethoxy)ethoxy]acetic acid (500 mg, $2.81 \mathrm{mmol}$ ) was stirred for $2 \mathrm{~h}$ at room temperature. The excess reagent was removed under reduced pressure, and the residue was dried at $60^{\circ} \mathrm{C}$ under vacuum to give [2-(2-methoxyethoxy)ethoxy]acetyl chloride as light yellow oil $(550 \mathrm{mg})$, which was used for the next step without further purification. The [2-(2-methoxyethoxy)ethoxy]acetyl chloride was added to a solution of 1 (320 mg, $0.318 \mathrm{mmol})$, DMF $(2.0 \mathrm{~mL})$, and triethylamine $(180 \mathrm{mg}, 1.78 \mathrm{mmol})$ at $0{ }^{\circ} \mathrm{C}$, and the solution was stirred for $24 \mathrm{~h}$ at $45^{\circ} \mathrm{C}$ under a nitrogen atmosphere. Water $(2.0 \mathrm{~mL})$ was added, and the solution was stirred for $10 \mathrm{~min}$. Aqueous solution of sodium carbonate $(2.0 \mathrm{~g} / 50 \mathrm{~mL})$ was added, and the solution was extracted with $\mathrm{CH}_{2} \mathrm{Cl}_{2}(6 \times 30 \mathrm{~mL})$. After removal of the solvent, the oily crude product was purified by SEC with methanol as eluent to afford dendron $6(365 \mathrm{mg}, 0.222 \mathrm{mmol})$ as a light-yellow oil in $70 \%$ yield: ${ }^{1} \mathrm{H}$ NMR $\left(400 \mathrm{MHz}, \mathrm{CDCl}_{3}\right) \delta 2.32$ $2.40(\mathrm{~m}, 12 \mathrm{H}), 2.57-2.64(\mathrm{~m}, 6 \mathrm{H}), 2.74-2.81(\mathrm{~m}$, 12H), 3.30-3.37 (m, 22H), 3.39 (s, 12H), 3.60-3.68 $(\mathrm{m}, 32 \mathrm{H}), 3.94(\mathrm{~s}, 8 \mathrm{H}), 5.44(\mathrm{~d}, J=6.8 \mathrm{~Hz}, 2 \mathrm{H}), 7.49$ (t, $J=8.0 \mathrm{~Hz}, 2 \mathrm{H}), 7.59(\mathrm{t}, J=8.0 \mathrm{~Hz}, 2 \mathrm{H}), 8.02$ (d, $J=8.0 \mathrm{~Hz}, 2 \mathrm{H}), 8.29(\mathrm{~d}, J=8.0 \mathrm{~Hz}, 2 \mathrm{H}), 8.48$ (s, $1 \mathrm{H}) ;{ }^{13} \mathrm{C}$ NMR $\left(100 \mathrm{MHz}, \mathrm{CDCl}_{3}\right) \delta 32.5,38.7$, 51.6, 58.7, 58.8, 61.5, 68.4, 70.0, 70.1, 70.2, 70.3, $70.3,70.4,70.7,71.6,71.7,125.0,125.1,125.4$, 
125.7, 127.0, 131.2, 133.3, 134.0, 170.7, 170.8, 173.0; MALDI-TOF-Mass for $\mathrm{C}_{77} \mathrm{H}_{127} \mathrm{~N}_{15} \mathrm{O}_{24}: \mathrm{m} / z$ calcd., $1647.93\left[\mathrm{MH}^{+}\right]$; found: 1648.31 .

\section{Preparation of Hydrophilic Dendron 7}

To a solution of dendron $2(150 \mathrm{mg}, 0.0780 \mathrm{mmol})$ in $\mathrm{EtOH} / \mathrm{CH}_{3} \mathrm{CN}(1 / 1: 4 \mathrm{~mL})$ was added DIPEA (135 mg, $1.04 \mathrm{mmol}$ ), [2-(2-methoxyethoxy)ethoxy]acetic acid (134 mg, $0.788 \mathrm{mmol})$, and HOBt (141 mg, $1.04 \mathrm{mmol}$ ). After stirring for $5 \mathrm{~min}$ at room temperature under a nitrogen atmosphere, EDC hydrochloride (200 mg, $1.04 \mathrm{mmol}$ ) was added. After stirring at room temperature for $24 \mathrm{~h}$, the mixture was evaporated. The residue was purified by SEC with methanol as eluent to afford the dendron $7(115 \mathrm{mg}, 0.0359 \mathrm{mmol})$ as light-yellow oil in $58 \%$ yield: ${ }^{1} \mathrm{H}$ NMR $(400 \mathrm{MHz}$, $\left.\mathrm{CDCl}_{3}\right) \delta 2.25-2.40(\mathrm{~m}, 28 \mathrm{H}), 2.45-2.65(\mathrm{~m}, 14 \mathrm{H})$, 2.64-2.82 (m, 28H), 3.30-3.37 (m, 46H), $3.56(\mathrm{~s}$, 24H), 3.60-3.69 (m, 64H), $3.96(\mathrm{~s}, 16 \mathrm{H}), 5.45(\mathrm{~d}$, $J=6.8 \mathrm{~Hz}, 2 \mathrm{H}), 7.49(\mathrm{t}, J=8.0 \mathrm{~Hz}, 2 \mathrm{H}), 7.59(\mathrm{t}$, $J=8.0 \mathrm{~Hz}, 2 \mathrm{H}), 8.02(\mathrm{~d}, J=8.0 \mathrm{~Hz}, 2 \mathrm{H}), 8.29(\mathrm{~d}$, $J=8.0 \mathrm{~Hz}, 2 \mathrm{H}), 8.48(\mathrm{~s}, 1 \mathrm{H}) ;{ }^{13} \mathrm{C}$ NMR $(100 \mathrm{MHz}$, $\left.\mathrm{CDCl}_{3}\right) \delta 33.5,33.9,34.1,36.3,37.5,39.0,39.2,39.3$, $39.5,50.0,52.0,52.6,59.1,70.4,70.5,71.1,72.0$, $77.4,77.7,78.1,124.0,125.0,125.4,127.0,127.7$, 129.4, 130.6, 131.7, 160.0, 160.1, 172.9, 173.1, 173.3; MALDI-TOF-Mass for $\mathrm{C}_{145} \mathrm{H}_{255} \mathrm{~N}_{31} \mathrm{O}_{48}: \mathrm{m} / z$ calcd, $3200.76\left[\mathrm{MH}^{+}\right]$; Found: 3201.15 .

\section{Photodimerization of Hydrophobic Dendron 3}

A solution of dendron $3(25 \mathrm{mg}, 0.012 \mathrm{mmol})$ in chloroform/methanol $(5 / 1: 300 \mu \mathrm{L})$ was irradiated with a high-pressure mercury lamp through a Pyrex filter for $6 \mathrm{~h}$ at room temperature. After removal of the solvent, the reaction mixture was dissolved in $\mathrm{CDCl}_{3} / \mathrm{CD}_{3} \mathrm{OD}(10 / 1)$ for ${ }^{1} \mathrm{H}$ NMR analysis.

\section{Photodimerization of Hydrophilic Dendron 7}

A solution of dendron $7(50 \mathrm{mg}, 0.015 \mathrm{mmol})$ in $\mathrm{CDCl}_{3}(250 \mu \mathrm{L})$ was irradiated with a high-pressure mercury lamp through a Pyrex filter for $4 \mathrm{~h}$ at room temperature. After removal of the solvent, the residue was purified by SEC with methanol as eluent to isolate the dendron 7 (4 mg, $0.0006 \mathrm{mmol}$ ) as light-yellow oil in $8 \%$ yield: ${ }^{1} \mathrm{H}$ NMR $\left(400 \mathrm{MHz}, \mathrm{CDCl}_{3}\right) \delta 2.25-3.14$ (m, $140 \mathrm{H}), 3.22-3.45(\mathrm{~m}, 140 \mathrm{H}), 3.50-3.75(\mathrm{~m}, 128 \mathrm{H})$, $4.08(\mathrm{~s}, 32 \mathrm{H}), 4.54(\mathrm{~s}, 4 \mathrm{H}), 4.06(\mathrm{~s}, 2 \mathrm{H}), 6.78-7.00(\mathrm{~m}$, $16 \mathrm{H}), 7.45-7.70(\mathrm{~m}, 24 \mathrm{H}), 7.72-8.50(\mathrm{~m}, 24 \mathrm{H})$.

\section{Preparation of Surface-Block Dendrimer 11}

A mixture of $5(19 \mathrm{mg}, 0.012 \mathrm{mmol})$ and $7(39 \mathrm{mg}$, $0.012 \mathrm{mmol})$ was dissolved in $\mathrm{CDCl}_{3} / \mathrm{CD}_{3} \mathrm{OD}(5 / 1$ : $360 \mu \mathrm{L}$ ) and irradiated with a high-pressure mercury lamp through a Pyrex filter for $4 \mathrm{~h}$ at room temperature. After removal of the solvent, the mixture was purified by SEC with chloroform as eluent to afford dendrimer $11(8.5 \mathrm{mg}, 0.0018 \mathrm{mmol})$ in $22 \%$ yield: ${ }^{1} \mathrm{H} \mathrm{NMR}\left(\mathrm{CDCl}_{3}\right) \delta 0.81(\mathrm{t}, J=7.6 \mathrm{~Hz}, 12 \mathrm{H}), 1.17-$ $1.31(\mathrm{~m}, 48 \mathrm{H}), 2.11(\mathrm{t}, J=7.6 \mathrm{~Hz}, 8 \mathrm{H}), 2.29-2.35(\mathrm{~m}$, $40 \mathrm{H}), 2.40-2.58(\mathrm{~m}, 20 \mathrm{H}), 2.61-2.78(\mathrm{~m}, 40 \mathrm{H}), 3.24-$ $3.30(\mathrm{~m}, 68 \mathrm{H}), 3.30(\mathrm{~s}, 24 \mathrm{H}), 3.57-3.61(\mathrm{~m}, 64 \mathrm{H})$, $3.64(\mathrm{~s}, 2 \mathrm{H}), 3.91(\mathrm{~s}, 16 \mathrm{H}), 4.05-4.12(\mathrm{~m}, 2 \mathrm{H}), 4.53$ (s, 4H), 6.77-6.86 (m, 16H); MALDI-TOF-Mass for $\mathrm{C}_{230} \mathrm{H}_{398} \mathrm{~N}_{46} \mathrm{O}_{60}: \mathrm{m} / z$ calcd, $4768.90\left[\mathrm{MH}^{+}\right]$; found: 4768.19 .

Photo-irradiation of Mixture 5 and 7 without Solvent A mixture of 5 (19 mg, $0.012 \mathrm{mmol})$ and $7(39 \mathrm{mg}$, $0.012 \mathrm{mmol}$ ) was dissolved in chloroform $/$ methanol (5/1). After removal of the solvent in vacuo, the residue was irradiated with a high-pressure mercury lamp through a Pyrex filter for $6 \mathrm{~h}$ at room temperature. The resulting mixture was analyzed by the use of SEC with chloroform as eluent.

\section{Photo-irradiation of Emulsion of a Mixture 5 and 7}

A mixture of 5 (19 mg, $0.012 \mathrm{mmol})$ and $7(39 \mathrm{mg}$, $0.012 \mathrm{mmol})$ was dissolve in toluene/methanol $(5 / 1$ : $0.5 \mathrm{~mL}$ ). The solution was mixed with $5 \mathrm{~mL}$ of dilute hydrochloric acid (pH 3) to give a lacteous emulsion. The emulsion was irradiated with a high-pressure mercury lamp through a Pyrex filter for $6 \mathrm{~h}$ at room temperature. After removal of the solvent, the residue was analyzed by the use of SEC with chloroform as eluent.

\section{RESULTS AND DISCUSSION}

In order to prepare the surface-block dendrimer via the divergent/convergent approach, various poly(amidoamine) dendrons were synthesized by the divergent method and subsequent modifications of terminal groups. As precursors, dendrons 1 and 2 possessing $\mathrm{NH}_{2}$ groups at the terminals were prepared as described before. ${ }^{17}$ Hydrophobic alkyl arms were introduced by amidation of the surface $\mathrm{NH}_{2}$ groups of dendrons 1 and $\mathbf{2}$ with octadecanoyl chloride to give dendrons $\mathbf{3}$ and 4 in $12 \%$ and $4 \%$ yield, respectively (Scheme 1). On the other hand, amidation of the surface $\mathrm{NH}_{2}$ groups of dendron 1 with nonanoic acid was carried out in the presence of EDC, HOBt, and DIPEA for $1 \mathrm{~d}$ at room temperature in $\mathrm{EtOH} / \mathrm{CH}_{3} \mathrm{CN}(1 / 1)$ to give dendron 5 in $58 \%$ yield (Scheme 2). Compounds 3-5 are insufficiently soluble in conventional solvents but are soluble in a mixed solvent (chloroform/methanol). Meanwhile, hydrophilic arms were introduced through amidation of the surface $\mathrm{NH}_{2}$ groups of dendron 1 with [2-(2-methoxyethoxy)ethoxy] acetyl chloride to give dendron 6 in $70 \%$ yield (Scheme 1). Dendron 7 was obtained in 58\% yield (Scheme 2) when 


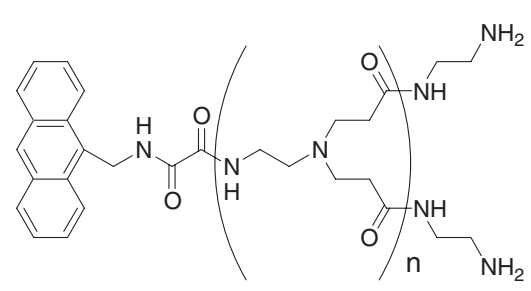

1: $n=2$

2: $n=3$

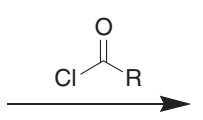

3: $\mathrm{n}=2, \mathrm{R}=\left(\mathrm{CH}_{2}\right)_{16} \mathrm{CH}_{3}$

4: $\mathrm{n}=3, \mathrm{R}=\left(\mathrm{CH}_{2}\right){ }_{16} \mathrm{CH}_{3}$

6: $\mathrm{n}=2, \mathrm{R}=\mathrm{CH}_{2} \mathrm{OCH}_{2} \mathrm{CH}_{2} \mathrm{OCH}_{2} \mathrm{CH}_{2} \mathrm{OCH}_{3}$

Scheme 1. Synthesis of the dendrons 3, 4 and 6.

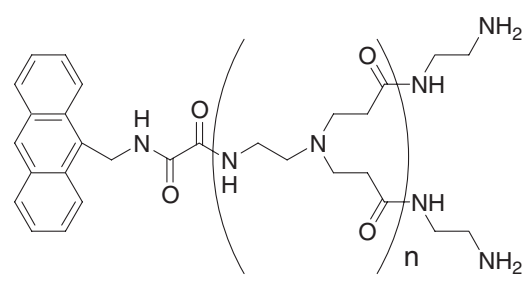

$1: \mathrm{n}=2$

2: $\mathrm{n}=3$

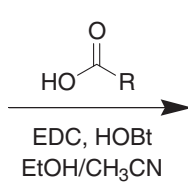

5: $\mathrm{n}=2, \mathrm{R}=\left(\mathrm{CH}_{2}\right)_{7} \mathrm{CH}_{3}$

7: $\mathrm{n}=3, \mathrm{R}=\mathrm{CH}_{2} \mathrm{OCH}_{2} \mathrm{CH}_{2} \mathrm{OCH}_{2} \mathrm{CH}_{2} \mathrm{OCH}_{3}$

Scheme 2. Synthesis of the dendrons 5 and 7.

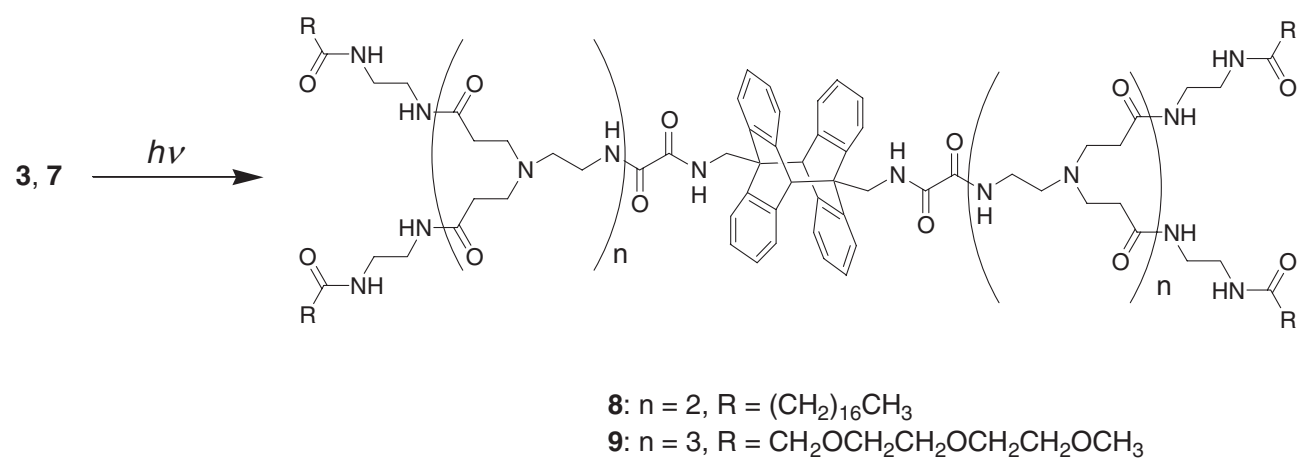

Scheme 3. Photodimerization of dendrons 3 and 7.

dendron 2 was allowed to react with [2-(2-methoxyethoxy)ethoxy] acetic acid in the presence of EDC, HOBt, and DIPEA for $1 \mathrm{~d}$ at room temperature in $\mathrm{EtOH} / \mathrm{CH}_{3} \mathrm{CN}(1 / 1)$. The structures of dendrons 3-7 were confirmed by ${ }^{1} \mathrm{H},{ }^{13} \mathrm{C}$ NMR spectroscopies, and MALDI-TOF-Mass. The MALDI-TOF spectra of dendrons 3-7 clearly showed the parent peaks at $\mathrm{m} / \mathrm{z}$ 2073.50, 4052.18, 1567.65, 1648.31, and 3201.15, which are consistent with the molecular weights of the dendrons 3-7 $\left(\left[\mathrm{MH}^{+}\right]\right.$, calcd. 2073.11, 4051.11, 1568.15, 1647.93, and 3200.76), respectively.

In order to clarify the photoreactivity of the anthryl dendrons, photodimerizations of dendrons $\mathbf{3}$ and $\mathbf{7}$ were examined as shown in Scheme 3. A solution (chloroform $/$ methanol $=5 / 1$ ) of dendron 3 was irradiated with a high-pressure mercury lamp $(\lambda>300$ $\mathrm{nm}$ ) for $6 \mathrm{~h}$ at room temperature under a nitrogen atmosphere to afford the corresponding photodimer 8 in $84 \%$ yield, which was estimated by ${ }^{1} \mathrm{H}$ NMR analysis of the reaction mixture. Unfortunately, the photodimer 8 could not be isolated by silica-gel column chromatography and size-exclusion chromatography (SEC) because of its poor solubility. On the other hand, a chloroform solution of dendron 7 was irradiated with the high-pressure mercury lamp $(\lambda>300 \mathrm{~nm})$ for $4 \mathrm{~h}$ at room temperature under nitrogen atmosphere to afford photodimer 9, which was isolated by the SEC, in $80 \%$ yield. 


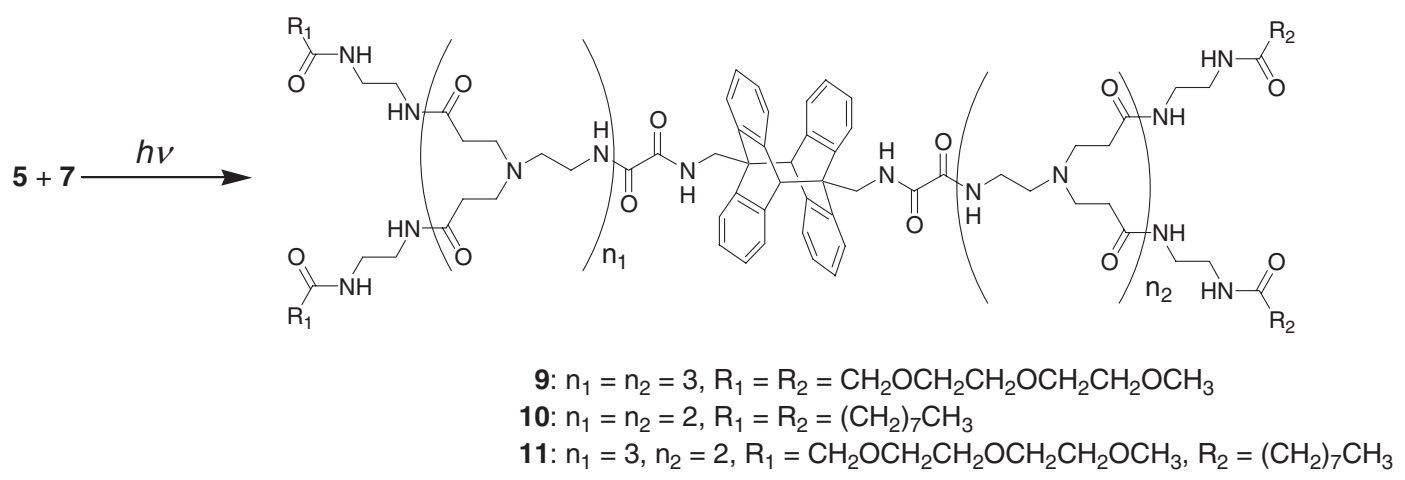

Scheme 4. Synthesis of surface-block dendrimer 11.

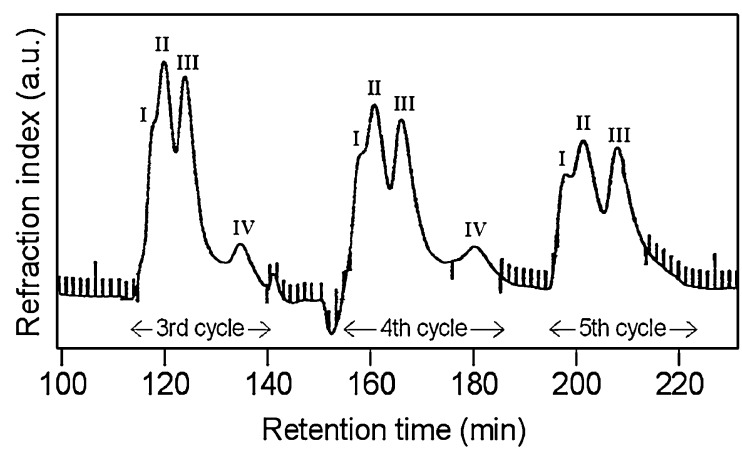

Figure 1. Chromatogram of recycling SEC of reaction mixture obtained by photocycloaddition reaction of mixture of $\mathbf{5}$ and $\mathbf{7}$ in solution. (Fraction corresponding to peak IV was removed from the recycling process in 4 th cycle.)

For the purpose of formation of surface-block dendrimer, photocycloadditons of the hydrophobic dendrons 3-5 with the hydrophilic dendrons 6 and 7 were examined. Unfortunately, when hydrophobic dendron 3 was employed for the photocycloaddition with hydrophilic dendrons 6 and 7, surface-block dendrimers were not isolated because of poor solubility. Formation of a surface-block dendrimer 11 was finally accomplished, as shown in Scheme 4. A solution (chloroform/methanol $=5 / 1$ ) of dendrons 5 and 7 was irradiated with the high-pressure mercury lamp $(\lambda>300 \mathrm{~nm})$ for $4 \mathrm{~h}$ at room temperature under a nitrogen atmosphere. Consequently, a mixture of three photodimers 9 (dimer of $\mathbf{5}$ ), $\mathbf{1 0}$ (dimer of 7), and heterodimer 11 were obtained in $70 \%$ yield that was estimated by ${ }^{1} \mathrm{H}$ NMR analysis of the reaction mixture. In order to separate the desired surface block dendrimer 11, SEC experiment was performed on a HPLC (LC918, Japan Analytical Industry, Co. Ltd.) equipped with differential refractometer (RI-50) and gel permeation column (Jaigel $1 \mathrm{H}+2.5 \mathrm{H}$ ) with chloroform as eluent. Figure 1 shows a part of the typical recycling chromatogram of the reaction mixture. After four or more recycling processes (repeat passages through the columns), the chromatogram shows four dominant peaks that were numbered I, II, III, and $\mathbf{I V}$, in order of increasing retention time. These peaks were respectively assigned to $\mathbf{9 , 1 1 , 7 / 1 0}$ and 5 by ${ }^{1} \mathrm{H}$ NMR analysis of fractions collected from the several peaks. These assignments were supported by molecular weights of 9 (MW: 6400), 11 (MW: 4767), 7 (MW: 3200), 10 (MW: 3134), and 5 (MW: 1567), which are consistent with the retention times. To isolate the surface-block dendrimer 11, fractions from I, III and IV were carefully removed from the recycling processes in each cycle. At last, fraction from II was collected and the dendrimer $\mathbf{1 1}$ was obtained in $22 \%$ yield. The structure of dendrimer 11 was confirmed by ${ }^{1} \mathrm{H}$ NMR spectroscopy and MALDI-TOF-Mass. The anthracenes proton signals [ $\delta 7.51(\mathrm{t}, 2 \mathrm{H}), 7.57(\mathrm{t}, 2 \mathrm{H}), 8.07(\mathrm{~d}, 2 \mathrm{H}), 8.29(\mathrm{~d}$, $2 \mathrm{H}), 8.52(\mathrm{~s}, 1 \mathrm{H}) ; \delta 7.49(\mathrm{t}, 2 \mathrm{H}), 7.59(\mathrm{t}, 2 \mathrm{H}), 8.02$ $(\mathrm{d}, 2 \mathrm{H}), 8.29(\mathrm{~d}, 2 \mathrm{H}), 8.48(\mathrm{~s}, 1 \mathrm{H})]$ of dendrons 5 and 7 in $\mathrm{CDCl}_{3}$ disappeared and new multiplet peaks appeared at $6.77-6.86 \mathrm{ppm}$ which consist with formation of the anthracene dimer. Two methylene proton signals $[\delta 5.48(\mathrm{~s}, 2 \mathrm{H}), 5.45(\mathrm{~d}, 2 \mathrm{H})]$ of anthracenes' 9-positions of dendrons 5 and $\mathbf{7}$ disappeared and a new peak appeared at $4.53 \mathrm{ppm}$. The MALDI-TOFMass spectrum of $\mathbf{1 1}$ showed the parent peak at $\mathrm{m} / \mathrm{z}$ 4768.19, which is consistent with the molecular weight of the dendrimer $11\left(\left[\mathrm{MH}^{+}\right]\right.$, calcd. 4768.90) as shown in Figure 2, although signals for the dendrons 5, 7 generated by laser irradiation in the MALDI process via retro-cycloaddition reaction were much more strongly observed than the parent peak. The ratio of the photoproducts $\mathbf{1 1} / \mathbf{1 0} / \mathbf{9}$ was estimated to be $47 \% / 29 \% / 24 \%$ by means of area raio of $\mathbf{I} / \mathbf{I I} / \mathbf{I I I}$ of the chromatogram, which was obtained by Gaussian fitting, and ${ }^{1} \mathrm{H}$ NMR spectrum of the fraction from III (Table I).

Recently, we reported regio-selective photodimerizations of anthracenes bearing a dendritic substituent, which proceed in their liquid crystalline phase ${ }^{22}$ or micellar aggregates, ${ }^{23}$ and revealed that the regio-selectivities are reflected in unique molecular orienta- 


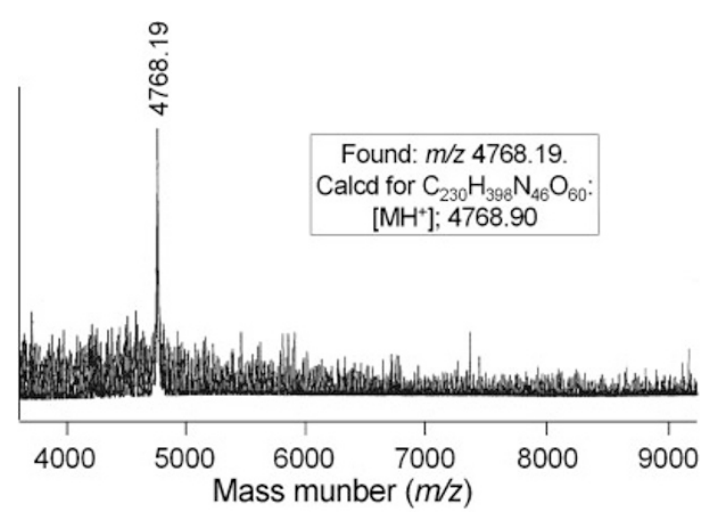

Table I. Ratio of the photoproducts $11 / \mathbf{1 0} / \mathbf{9}$

\begin{tabular}{lccc}
\hline & $\mathbf{1 1}$ & $\mathbf{1 0}$ & $\mathbf{9}$ \\
\hline solution & $47 \%$ & $29 \%$ & $24 \%$ \\
neat & $50 \%$ & $32 \%$ & $18 \%$ \\
emulsion & - & - & $100 \%$ \\
\hline
\end{tabular}

Figure 2. MALDI-TOF spectrum of surface-block dendrimer 11.

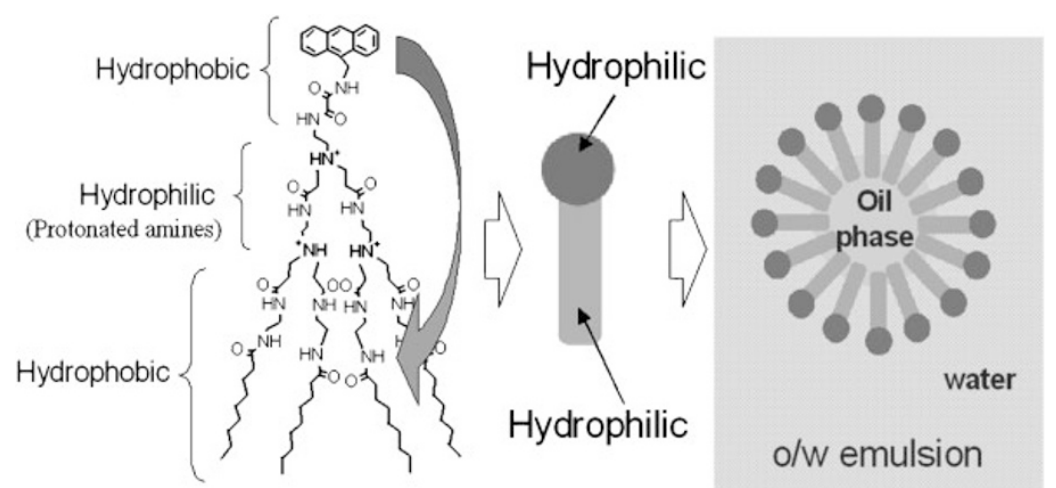

Figure 3. Schematic representation of the micelle formation of dendron $\mathbf{5}$ in o/w emulsion.

tions in such conditions. For the sake of development of a methodology that can more efficiently produce surface-block dendrimer via divergent/convergent approach, the photocycloadditions were attempted in solvent free and an emulsion condition where the molecular orientations might be different form in the case of the solution. The evaporated mixture of dendrons 5 and 7 was irradiated with the high-pressure mercury lamp for $6 \mathrm{~h}$ under a nitrogen atmosphere to afford photodimers 9-11 in 39\% yield; the ratio of the photoproducts 11/10/9 was estimated to be $50 \% / 32 \%$ / $18 \%$. (Table I). Meanwhile, the o/w emulsion was prepared by mixing a solution of dendrons 5 and 7 in toluene/MeOH $(100 / 1)$ and dilute hydrochloric acid ( $\mathrm{pH} 3$ ). The emulsion was irradiated with the high-pressure mercury lamp $(\lambda>300 \mathrm{~nm})$ for $6 \mathrm{~h}$ under a nitrogen atmosphere to afford only photodimer 9 in $28 \%$ yield. Interestingly, the formations of photoproducts 10 and 11 were not detected implying that photoreaction of dendron $\mathbf{5}$ was hampered when the $\mathrm{o} / \mathrm{w}$ emulsion was used as a reaction medium. This might have occurred because dendron 5 at oil-water interface of the emulsion was folded up into a compact form, i.e., the hydrophobic anthracene moiety and the alkyl chains will orient toward the oil phase, whereas hydrophilic protonated poly(amidoamine) building block will orient toward the polar phase, as shown in Figure 3. Thus, we could not succeed in selective formation of the surface block dendrimer, but we found the example of collecting information about molecular orientation in emulsion by the use of photoreaction.

\section{CONCLUSION}

The results described herein show the first example of a surface-block dendrimer formed by photoreaction. The divergent/convergent approach to synthesis of surface-block dendrimer was achieved by the use of [4+4] photocycloaddition of anthracenes bearing two different dendritic substituents, of which terminal groups are long alkyl chains for one hemisphere and oligo(ethylene oxide) chains for the other hemisphere. Further work is in progress to explore the applications and advantages of this novel approach for synthesis of surface-block dendrimer.

Acknowledgment. This work partly supported by The Kurata Memorial Hitachi Science and Technology Foundation, Industrial Technology Research Grant Program in 2004 from New Energy and Industrial Technology Development Organization (NEDO) 
of Japan, and Grant-in-Aid for the Scientific Research (15550036, 15750036) from the Ministry of Education, Culture, Sports, Science and Technology (MEXT), Japan.

\section{REFERENCES}

1. "Dendrimers and Other Dendritic Polymers," J. M. J. Fréchet and D. A. Tomalia, Ed., John Wiley \& Sons, Chichester, 2001.

2. "Dendrimers, Topics in Current Chemistry," F. Vögtle, Ed., Springer, Berlin, 1998, vol. 197.

3. "Dendrimers II, Topics in Current Chemistry," F. Vögtle, Ed., Springer, Berlin, 2000, vol. 210.

4. "Dendrimers III, Topics in Current Chemistry," F. Vögtle, Ed., Springer, Berlin, 2001, vol. 212.

5. "Dendrimers IV, Topics in Current Chemistry," F. Vögtle and C. A. Schalley, Ed., Springer, Berlin, 2001, vol. 217.

6. D. C. Tully and J. M. J. Fréchet, Chem. Commun., 1229 (2001).

7. C. J. Hawker and J. M. J. Fréchet, Macromolecules, 23, 4726 (1990).

8. C. J. Hawker, K. L. Wooley, and J. M. J. Fréchet, Macromol. Symp., 77, 11 (1994).

9. S. M. Grayson and J. M. J. Fréchet, J. Am. Chem. Soc., 122, 10335 (2000).

10. K. Aoi, K. Itoh, and M. Okada, Macromolecules, 30, 8072 (1997).

11. V. Maraval, R. Laurent, B. Dommadieu, M. Mauzac, A.-M. Caminade, and J.-P. Majoral, J. Am. Chem. Soc., 122, 2499 (2000).
12. K. Aoi, H. Noda, K. Tsutsumiuchi, and M. Okada, "37th IUPAC International Symposium on Macromolecules, Preprints," 1998, p. 765.

13. T. Imae, M. Ito, K. Aoi, K. Tsutsumiuchi, H. Noda, and M. Okada, Colloids Surf., A, 175, 225 (2000).

14. V. Maraval, R.-M. Sebastian, F. Ben, R. Laurent, A.-M. Caminade, and J.-P. Majoral, Eur. J. Inorg. Chem., 2001, 1681 (2001).

15. M. Ito, T. Imae, K. Aoi, K. Tsutsumiuchi, H. Noda, and M. Okada, Langmuir, 18, 9757 (2002).

16. V. Percec, M. R. Iman, T. K. Bera, V. S. K. Balagurusamy, M. Peterca, and P. A. Heiney, Angew. Chem., Int. Ed., 44, 4739 (2005).

17. Y. Takaguchi, T. Tajima, K. Ohta, J. Motoyoshiya, and H. Aoyama, Chem. Lett., 29, 1388 (2000).

18. Y. Takaguchi, T. Tajima, K. Ohta, J. Motoyoshiya, H. Aoyama, T. Wakahara, T. Akasaka, M. Fujitsuka, and O. Ito, Angew. Chem., Int. Ed., 41, 817 (2002).

19. Y. Takaguchi, Y. Yanagimoto, T. Tajima, K. Ohta, J. Motoyoshiya, and H. Aoyama, Chem. Lett., 31, 1102 (2002).

20. Y. Takaguchi, Y. Sako, Y. Yanagimoto, S. Tsuboi, J. Motoyoshiya, H. Aoyama, T. Wakahara, and T. Akasaka, Tetrahedron. Lett., 44, 5777 (2003).

21. M. Fujitsuka, O. Ito, Y. Takaguchi, T. Tajima, K. Ohta, J. Motoyoshiya, and H. Aoyama, Bull. Chem. Soc. Jpn., 76, 743 (2003).

22. Y. Takaguchi, T. Tajima, Y. Yanagimoto, S. Tsuboi, K. Ohta, J. Motoyoshiya, and H. Aoyama, Org. Lett., 5, 1677 (2003).

23. Y. Yanagimoto, Y. Takaguchi, Y. Sako, S. Tsuboi, M. Ichihara, and K. Ohta, Tetrahedron, 62, 8373 (2006). 